\title{
Adaptation and validation of the measure of organizational citizenship behavior in collaborative learning
}

\author{
Sung Pil Kang \\ University of New Mexico, Albuquerque, NM, USA \\ JaeHwan Byun \\ Wichita State University, Wichita, KS, USA \\ Victor Law \\ University of New Mexico, Albuquerque, NM, USA \\ Youn Kyung Seo \\ Seoul Women's University, Seoul, Korea \\ Kristen Ferris \\ University of New Mexico, Albuquerque, NM, USA
}

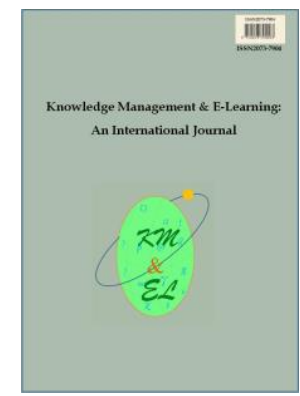

Knowledge Management \& E-Learning: An International Journal (KM\&EL) ISSN 2073-7904

\section{Recommended citation:}

Kang, S. P., Byun, J., Law, V., Seo, Y. K., \& Ferris, K. (2020). Adaptation and validation of the measure of organizational citizenship behavior in collaborative learning. Knowledge Management \& E-Learning, 12(3), 280-297. https://doi.org/10.34105/j.kmel.2020.12.015 


\title{
Adaptation and validation of the measure of organizational citizenship behavior in collaborative learning
}

\author{
Sung Pil Kang \\ Organization, Information \& Learning Sciences Program \\ University of New Mexico, Albuquerque, NM, USA \\ E-mail: pilkang@unm.edu
}

\section{JaeHwan Byun}

School of Education, College of Applied Studies

Wichita State University, Wichita, KS, USA

E-mail: Jaehwan.Byun@wichita.edu

\section{Victor Law*}

Organization, Information \& Learning Sciences Program

University of New Mexico, Albuquerque, NM, USA

E-mail: vlaw@unm.edu

\section{Youn Kyung Seo}

Institute of General Education

Seoul Women's University, Seoul, Korea

E-mail: yunks@swu.ac.kr

\section{Kristen Ferris}

Organization, Information \& Learning Sciences Program

University of New Mexico, Albuquerque, NM, USA

E-mail: ferriskristenl@gmail.com

\section{*Corresponding author}

\begin{abstract}
Organizational citizenship behavior refers to "individual behavior that is discretionary, not directly or explicitly recognized by the formal reward system, and that in the aggregate promotes the effective functioning of the organization (Organ, 1988, p. 4)". Previous research suggests organizational citizenship behavior can be a beneficial concept in a collaborative learning setting because it may affect learning outcomes, student satisfaction, and social loafing in organizations and teams. However, a measure of organizational citizenship behavior in the collaborative learning setting does not exist. This research aimed to adapt and validate the measurement of organizational citizenship behavior in a collaborative learning setting. 511 college students in Korea participated in this study. First, we conducted exploratory analysis, and as a result, four dimensions were extracted: altruism, conscientiousness, sportsmanship, and courtesy. Subsequently, we conducted confirmatory factor
\end{abstract}


analysis to examine the stability of multidimensionality, and the result indicated the four-factor structure has a reasonable fit statistically. In addition, we examined convergent, discriminant and criterion validities. With this validated measurement, future studies can examine how organizational citizenship behavior in the collaborative learning is related to other learning constructs such as student engagement and academic achievement.

Keywords: Organizational citizenship behavior; Collaborative learning; Scale; Validation; Adaptation

Biographical notes: Dr. Sung "Pil" Kang is an assistant professor at the University of New Mexico. He has had the privilege of working with global companies and intergovernmental organizations including Bank of America, McDonald's, and Asia-Pacific Economic Cooperation (APEC). His academic interests include change management, OCB, knowledge sharing and social capital.

Dr. JaeHwan Byun is an assistant professor of the Master of Education in Learning and Instructional Design program in the School of Education of College of Applied Studies at Wichita State University. The research topics he is interested in including digital game-based learning, students' engagement, and online learning.

Dr. Victor Law is an associate professor at the University of New Mexico. His research interests include computer-supported collaborative learning, scaffolding, and motivation. Dr. Law has published empirical studies in international refereed journals including International Journal of Knowledge Management and E-Learning, Computers and Education, and Computers in Human Behaviors.

Dr. Youn Kyung Seo is an associate professor at the Seoul Women's University. She is in charge of planning and operating the teaching method program at the Center for Teaching \& Learning, and works as an educational consultant in order to improve the quality of higher education. Her academic interests include teaching methods for active learning \& team-based learning, design \& development of effective instructions, faculty development.

Kristen Ferris is a doctoral student at the University of New Mexico where she is studying organizational design. Her research interests include change management and organizational citizenship behavior. She works at Central New Mexico Community College where she manages the accreditation and strategic planning processes.

\section{Introduction}

Collaborative learning is a widely used learner-centered instructional method in higher education settings, and it has been studied throughout academic literature (e.g., Aggarwal \& O'Brien, 2008; Balasooriya, Hughes, \& Toohey, 2009; Ching \& Hsu, 2013; Espey, 2010; Volet \& Mansfield, 2006). Collaborative learning is defined as "an instruction method in which students at various performance levels work together in small groups toward a common goal" (Gokhale, 1995, p. 22). Research has shown that students working collaboratively with other students learn more when compared to individual learning (Johnson \& Johnson, 1989). Furthermore, collaborative learning can develop 
students' social interaction skills and critical thinking skills, help students to create learning communities, build more positive relationships, encourage diversity understanding, and motivate them to learn (Aggarwal \& O'Brien, 2008; Deeter-Schmelz, Kennedy, \& Ramsey, 2002; Laal \& Ghodsi, 2012; Micari \& Pazos, 2019; Medero \& Albaladejo, 2020; Tlhoaele, Hofman, Winnips, \& Beetsma, 2014).

While there are many benefits, collaborative learning does not always provide students with successful or positive learning experiences. For example, students often have difficulties scheduling time with other students during collaboration (Gottschall \& García-Bayonas, 2008). Moreover, due to the gaps in the performance levels among group members, they may perceive group work negatively because of the inequality or inequity of the tasks assigned to individuals within the group (Gokhale, 1995; Myers, 2012). For successful collaborative learning experiences, students may need peer teamwork or collaborative learning skills (Balasooriya et al., 2009). In the current study, we explore one concept, which has the potential to positively influence collaborative learning, organizational citizenship behavior (OCB).

OCB refers to the "individual behavior that is discretionary, not directly or explicitly recognized by the formal reward system, and that in the aggregate promotes the effective functioning of the organization" (Organ, 1988, p. 4). OCB of collaborators can improve the team's collaborative performance., Their engagement and satisfaction are also enhanced because OCB can ease tensions related to work processes and group dynamics in organizations (Bateman \& Organ, 1983; Lin \& Peng, 2010; Podsakoff \& Mackenzie, 1997). OCB is a concept originating in the field of business and widely used in the fields of management, organizational psychology, and human resource development, which later is extended to work teams (Nielsen, Hrivnak, \& Shaw, 2009). If we consider a group of college students in a collaborative learning setting as a work team that aims to produce a satisfying outcome through effective working processes, it is reasonable to theorize OCB in collaborative learning environments.

Despite the potential benefits of OCB for students' collaborative learning experiences, few OCB studies have been conducted in educational contexts. The existing studies of OCB in education mainly focus on the teachers' OCB in secondary school settings (e.g., Koh, Steers, \& Terborg, 1995; DiPaola \& Tschannen-Moran, 2001; DiPaola \& Hoy, 2005) or students' general OCB in school (e.g., Allison, Voss, \& Dryer, 2001; Chen \& Carey, 2009) rather than OCB in collaborative learning.

In order to research how $\mathrm{OCB}$ and its dimensions work specifically in collaborative learning environments, an instrument that measures OCB in this context is needed. Therefore, the current study aimed to introduce the concept of OCB to the field of collaborative learning in higher education, as well as adapt a measurement of OCB in collaborative learning contexts. Consequently, our study contributes to the collaborative learning research community for investigating further the various relationships of OCB with other constructs, such as students' leadership in a group work, engagement level in collaborative learning settings, and output produced by group work.

\section{Literature review}

\subsection{Dimension of $O C B$}

Dennis Organ, a renowned organizational psychologist, created the concept of OCB. Bateman and Organ (1983) found that employees' helping behaviors which were not a 
part of their job description (e.g., helping co-workers experiencing job-related issues) increased job satisfaction; they coined the term citizenship behavior.

OCB is a multi-dimensional construct (Podsakoff, Whiting, Podsakoff, \& Blume, 2009). OCB started with altruism and general compliance in the early research (Bateman \& Organ, 1983). Then, Organ (1988) proposed five factors of OCB which are altruism, conscientiousness, sportsmanship, courtesy, and civic virtue. Podsakoff, MacKenzie, Moorman, and Fetter (1990) operationalized the factors and validated the measures. The operationalized definitions of the factors are listed below:

Altruism: Discretionary behaviors that have the effect of helping a specific other with an organizationally relevant task or problem.

Conscientiousness: Discretionary behaviors on the part of the employee that go well beyond the minimum role requirements of the organization, in the areas of attendance obeying rules and regulations, taking breaks and so forth.

Sportsmanship: Willingness of the employee to tolerate less than ideal circumstances without complaining- to "avoid complaining, pretty grievances, railing against real or imagined slights, and making federal cases out of small potatoes."

Courtesy: Discretionary behavior on the part of an individual aimed at preventing work-related problems with others from occurring.

Civic Virtue: Behavior on the part of an individual that indicates that he/she responsibly participates in, is involved in, or is concerned about the life of the company. (Podsakoff et al., 1990, p.112)

\subsection{Consequences of $O C B$}

A substantial amount of research has shown significant relationships between OCB and other variables in organizations. OCB has been shown to increase employee satisfaction (Bateman \& Organ, 1983; Koys, 2001), team effectiveness (Walz \& Niehoff, 2000), and employee retention (Chahal \& Mehta, 2010). Moreover, OCB decreases employee absenteeism (Podsakoff et al., 2009), social loafing (Hoon \& Tan, 2008), and turnover rate (Sun, Aryee, \& Law, 2007).

As it does in organizations, OCB also influences the effectiveness of workgroups (Ehrhart \& Naumann, 2004). A meta-analysis of OCB in group contexts concluded that OCB is positively correlated with group performance and group dynamics (Nielsen et al., 2009; LePine, Piccolo, Jackson, Mathieu, \& Saul, 2008). Podsakoff, Ahearne, and MacKenzie (1997) found that altruism, courtesy, peacekeeping, and some aspects of cheerleading, could be positively connected to group effectiveness because the helping behavior of an experienced group member can help less-experienced group members solve work-related issues and identify effective methods to perform their jobs. Considering the OCB research results in business contexts, findings on employees and customer satisfaction may apply to student satisfaction in OCB. OCB research on employee absenteeism and turnover can give some hint about the relationship between OCB in education and student engagement or dropouts. Positive relationships between OCB and group performance and dynamics in a work group setting may also be expected in collaborative learning contexts. 


\section{3. $O C B$ in education}

Although OCB research findings in business contexts can be promising to the field of education, research efforts on OCB in education are scarce (Chen \& Carey, 2009). A few studies on OCB found in the field of education were mainly about teachers' OCB in secondary schools and about the students' OCB in secondary schools.

In the teacher OCB studies, researchers examine teachers' OCB and its relationship with principals' leadership (Koh et al., 1995), school climate (DiPaola \& Tschannen-Moran, 2001) and student academic performance (DiPaola \& Hoy, 2005). Those studies adapted Smith, Organ, and Near's (1983) two-dimensional OCB scale (altruism, compliance) to measure teachers' OCB. Koh et al. (1995) found three factors loaded in OCB (altruism, compliance one, and compliance two), but DiPaola and Tschannen-Moran (2001) found a unidimensional OCB. In all those studies, OCBs were found to positively relate to school constructs such as principle leadership, school climates, and student academic performance.

Regarding the students' OCB, two studies (Allison et al., 2001; Chen \& Carey, 2009) measure student citizenship behavior in the school context, and both showed the positive relationship between student $\mathrm{OCB}$ and other variables such as academic performance and student motivation. Allison et al. (2001) measured student general OCB in school using the five OCB dimensions: altruism, conscientiousness, sportsmanship, courtesy, and civic virtue. The authors combined two scales from two studies (Podsakoff \& MacKenzie, 1994; MacKenzie, Podsakoff, \& Fetter, 1993), and adapted the measurement items to the school context. The research showed that student OCB was correlated with academic performance. However, they did not report the validity of the OCB measure adapted to education.

Chen and Carey (2009) used a different scale to measure citizenship behavior in a college setting. Based on their exploratory factor analysis, they identified two dimensions of educational citizenship behavior (ECB), which were self-regulation and other orientation. They found that ECB was correlated with student motivation.

\section{4. $O C B$ and collaborative learning}

Collaborative learning is an instructional strategy where students work together through grouping or pairing to achieve an academic goal (Gokhale, 1995). Dillenbourg (1999) defines collaborative learning as a situation where "particular forms of interaction among people are expected to occur, which would trigger learning mechanisms" (p. 5). In classroom settings, collaborative learning provides "structured group activities for students and promote social skills students need to work together" (Goodsell, Maher, Tinto, Smith, \& MacGregor, 1992, p. 7).

Through successful collaborative learning, students receive a variety of benefits such as development of collaborative work skills (Knox, Gillis, \& Dake, 2019) which is considered even more important than content related knowledge or student grades (Kondo \& Faire, 2017). Additional benefits include critical thinking skills (Lee et al., 2016), increased student satisfaction (Espey, 2010), high productivity in group learning (Gillespie, Rosamond, \& Thomas, 2006), high learning motivation (Deeter-Schmelz et al., 2002), and better knowledge retention compared to traditional instructional methods (Alimoglu, Yardim, \& Uysal, 2017). Meta-analyses suggested that collaborative learning was more effective than individual learning in knowledge gains, skill development, perception of learning, transfer, and individual achievements (e.g., Chen, Wang, 
Kirschner, \& Tsai, 2018; Chen, Wang, Kirschner, \& Tsai, 2019; Lou, Abrami, \& d'Apollonia, 2001; Pai, Sears, \& Maeda, 2015).

Nonetheless, student participation in collaborative learning activities is sometimes challenging, and students often face negative experiences when they work in groups (Carpenter, 2006). The issues causing such challenges and negative experiences include managing time and schedule (Burdett, 2003; Gottschall \& García-Bayonas, 2008) as well as the existing gap in performance levels among group members (Gokhale, 1995). Students also get negative impressions of collaborative learning when they perceive inequality and inequity related to the tasks assigned to group members. The negative feelings create dysfunctional group dynamics and they eventually hinder student learning in the collaborative learning environment (Myers, 2012). Students may have difficulties receiving the benefits of collaborative learning environments when individuals do not show supportive behaviors related to the group work (Li, Kirkman, \& Porter, 2014).

Kreijns, Kirschner, and Jochems (2003) suggested that one of the pitfalls in collaborative learning research was the overemphasis of the cognitive aspects within collaborative learning. A valuable collaborative learning experience should include both social and cognitive processes. Gokhale (1995) suggested, to be productive and successful through collaborative learning, students within a group should help each other and take responsibility for the other students' learning, to view it as important as his or her own. In addition, several individual behaviors, which are dimensions of OCB, such as altruism and conscientiousness of students have shown positive effects on their performance in group work (Jungert, Van den Broeeck, Schreurs, \& Osterman, 2018). For example, Prasarnphanich and Wagner (2009) found that students' altruism is the usual driver for participation in collaborative knowledge creation. Delucchi (2006) found that the conscientiousness of students is positively related to grades on group projects and final exams. Goodsell et al. (1992) showed that courtesy was another attribute that students could develop through a collaborative learning experience.

Furthermore, if we view collaborative learning settings as work teams and consider the additional attributes of OCB, described previously. Then OCB could be considered one of the essential characteristics that students in collaborative learning situations should possess for promoting productive and successful collaborative learning experiences. Dimensions of OCB may be related to other variables in collaborative learning such as student helping behaviors, task responsibilities, and group dynamics, just as such dimensions of OCB do in workplace settings. OCB among group members can help maintain positive psychological structures in the group which facilitates the completion of group and individual tasks (Myers, 2012; Babcock-Roberson \& Stricklan, 2010). Likewise, if a student member in a group uses OCB, one can also contribute indirectly to the group, and eventually, the group will be productive. However, we cannot find research measuring nor investigating $\mathrm{OCB}$ as a whole in collaborative learning settings.

\subsection{An OCB measurement for collaborative learning}

In order to investigate how OCB and its dimensions work in collaborative learning environments, it is necessary to develop an instrument measuring OCB that fits this context. The previous studies indicate that there are universal OCB dimensions and context-specific dimensions (LePine, Erez, \& Johnson, 2002). Many OCB dimensions have been proposed and there are some significant overlapping factors among OCB studies. OCB research commonly measures universal dimensions only, or it measures 
universal ones with context-specific OCB dimensions (Farh, Zhong, \& Organ, 2004). In other words, the OCB dimensionality research has evolved from identifying the universal dimensions to adding and testing contextual ones. Since OCB research in the collaborative learning context has been scarcely conducted, it is reasonable to review the universal OCB dimensions first in order to examine whether universal ones are applicable. Thus, the current study adapted the OCB scale by Podsakoff et al. (1990), which is validated and frequently used, to develop the universal OCB dimensions for collaborative learning in higher education.

\section{Purpose}

The purpose of the study was to design and validate a new instrument to measure the OCB in collaborative learning contexts. To achieve this, we first identified the dimensions of OCB-CL. Then, we tested the validity of the new instrument. The following two research questions guided our study:

a. What are the dimensions of organizational citizenship behavior in collaborative learning (OCB-CL)?

b. To what extent does the four-factor model capture organizational citizenship behavior in collaborative learning (OCB-CL)?

\section{Methods}

\subsection{Context and participants}

The participants were college students at a women's university in Korea who were taking the course to fulfill graduation requirements. The class was a general education course that was required for every student from all majors within the university. The main goal of the course was to develop student knowledge and skills related to global citizenship. It was expected that after taking this course, students would play significant roles in their community as global citizens. Students learned about global citizenship in class, investigated current social issues, and suggested solutions for the issues through group projects. Two samples were collected over two semesters. The first sample was collected from 248 students, and the second sample was collected from 284 students enrolled in the same course the following year.

For both sample sets, the students met in class face-to-face twice a week. To ensure the effectiveness of the group activity, the students had a pre-group-activity session, in which students learned team-building skills, basic topic investigation skills, and various methods for problem-solving before they started their group work. The group activities took place over nine weeks during the semester. In each class session, students formed their own group of four or five people. A specific topic related to social issues was determined and discussed by the groups. Some example topics include, but are not limited to, teaching elementary students about racism, reducing the use of the products that contain palm oil to stop the exploitation of child labor, and fact-finding about the recycling status of single-person households. Each group conducted research on their chosen issue and made a presentation at the end of the semester.

The data were collected through a survey over two weeks. The total number of returned questionnaires was 525. Twenty-one cases were discarded because of 
incomplete surveys or multivariate outliers (Mahalanobis distance with $p<0.001$ ), 234 cases and 277 cases were used as sample \#1 and \#2 respectively. Sample \#1 was used for exploratory factor analysis, and sample \#2 was used for confirmatory factor analysis. Table 1 shows the demographic information of the subjects.

Table 1

Respondents' demographic data

\begin{tabular}{|c|c|c|c|c|c|c|c|}
\hline \multicolumn{2}{|c|}{ Categories } & \multicolumn{2}{|c|}{$\begin{array}{c}\text { Sample \#1 } \\
(N=234)\end{array}$} & \multicolumn{2}{|c|}{$\begin{array}{c}\text { Sample \#2 } \\
(\mathrm{N}=277)\end{array}$} & \multicolumn{2}{|c|}{$\begin{array}{c}\text { Total } \\
(\mathrm{N}=511)\end{array}$} \\
\hline & & $\mathrm{N}$ & $\%$ & $\mathrm{~N}$ & $\%$ & $\mathrm{~N}$ & $\%$ \\
\hline \multirow{3}{*}{$\begin{array}{l}\text { Year in } \\
\text { College }\end{array}$} & Junior & 184 & 78.6 & 237 & 85.6 & 421 & 82.4 \\
\hline & Senior & 50 & 21.4 & 39 & 14.1 & 89 & 17.4 \\
\hline & $\begin{array}{l}\text { Not } \\
\text { answered }\end{array}$ & 0 & 0 & 1 & 0.4 & 1 & 0.2 \\
\hline \multirow[t]{5}{*}{ Major } & Humanity & 53 & 22.6 & 54 & 19.5 & 107 & 20.9 \\
\hline & $\begin{array}{l}\text { Social } \\
\text { Science }\end{array}$ & 75 & 32.1 & 92 & 33.2 & 167 & 32.7 \\
\hline & Science & 55 & 23.5 & 59 & 21.3 & 114 & 22.3 \\
\hline & $\begin{array}{l}\text { Info. } \\
\text { Technology }\end{array}$ & 32 & 13.7 & 54 & 19.5 & 86 & 16.8 \\
\hline & Arts & 17 & 7.3 & 16 & 5.8 & 33 & 6.5 \\
\hline
\end{tabular}

\subsection{Instrumentation}

The OCB-CL survey was composed of two parts: demographic items and OCB-CL items. At the beginning of the survey, we asked for subject demographic data such as major and year in college.

\subsubsection{Adaptation of questionnaire}

For OCB-CL items, we adapted the OCB survey developed by Podsakoff et al. (1990) to the higher education context. For the OCB scale adaptation in the higher education setting, we formed an expert panel to examine the contextual equivalence and the face validity of the adapted scale (Sanson-Fisher \& Perkins, 1998; Keszei, Novak, \& Streiner, 2010). The expert panel consisted of five faculty members in human resources development and education fields. First, three faculty members in the fields of human resources development and education in the United States adapted the survey items in the collaborative learning context. The original OCB survey has 24 items in five dimensions. One of the original survey items was eliminated through the expert panel review because the item was not applicable to the collaborative learning setting, and then two university faculty members in the field of education in the United States checked and confirmed the face validity of the 23 items.

After confirming face validity, the survey items were translated into Korean based on a meticulous forward-backward translation procedure used in previous studies (e.g., Brislin, 1970; Lim, Morris, \& McMillan, 2011) to confirm semantic equivalence and compatibility between English and Korean versions of the survey. We formed a translation panel of four bilingual subject matter experts and conducted forward 
translation, cultural context check, and backward translation. For the forward translation, the original English version was translated into Korean by two Korean university faculties teaching in the United States. The translators were asked to consider the cultural aspects of both the US and Korea. After independent translations, the Korean versions were consolidated. For the cultural appropriateness check, the consolidated version was examined by a Korean professor in education in Korea. Then, the Korean version was back-translated into English by two social scientists who are native in English and proficient in Korean. Then, these translated versions were consolidated. The consolidated English version was compared with the OCB-CL survey items and confirmed the soundness of the survey translation.

The research participants were asked to respond to OCB-CL survey items by marking their agreement level on each item using a 5-point Likert scale (from $1=$ "strongly disagree" to 5 = "strongly agree").

\subsubsection{Engagement}

We measured student engagement to examine criterion validity in this research. We employed the engagement scale developed by Schaufeli, Salanova, González-Romá, and Bakker (2002) using a 5-point Likert scale (Sample item: When I am working in the group, I forget everything else around me).

\subsubsection{Social loafing}

Social loafing was also measured for criterion validity. The social loafing scale (5-point Likert scale) developed by George (1992) was adopted in this research (sample item: I work harder on my individual project than a group project).

\section{Results}

\subsection{Exploratory factor analysis}

We conducted an exploratory factor analysis with sample \#1 consisting of 234 cases using SPSS 25. Before running an exploratory factor analysis, we checked skewness and kurtosis of the items to check the normality assumption. The skewness range of the items is from -0.86 to -0.10 , and the kurtosis range of the items is from -0.78 to 0.66 . The absolute values of both skewness and kurtosis of all items are smaller than one, meaning they are substantially too small not to violate the normality assumption (Ferguson \& Cox, 1993; Fabrigar \& Wegener, 2012). KMO value was 0.907, and the Bartlett test of sphericity was significant $(p<0.05)$ which suggested sample adequacy and sufficient correlation among items (Hair, Black, Babin, Anderson, \& Tatham, 2006).

We included 23 items in the Exploratory Factor Analysis (EFA) using principal axis factoring with promax rotation (since the factors in the original OCB scales are highly correlated). In the first round of EFA, two survey items were deleted due to low communalities $(<0.4)$ (Costello \& Osborne, 2005). Then, with the criterion eigenvalues $>1$, four factors were extracted. However, three of the items had a loading value of less than .40 or the dual loading issue, meaning that the absolute values of factor loading of the items were higher than .35 to more than one factor (Hair et al., 2006). 
As a result, we deleted those three items and reran the EFA (Tabachnick \& Field, 2007). The EFA resulted in a four-factor structure, which explained $65.38 \%$ of the variance (see Table 2). Finally, we made sure all the factors had a minimum of three items to ensure a strong factor structure (e.g., Costello \& Osborne, 2005; Russell, 2002). The final four factors were conscientiousness, altruism, courtesy, and sportsmanship.

Table 2

Four-factor solutions for OCB-CL

\begin{tabular}{|c|c|c|c|c|c|c|}
\hline & \multicolumn{4}{|c|}{ Factor Loadings* } & \multirow[b]{2}{*}{$\mathrm{M}(\mathrm{SD})$} & \multirow[b]{2}{*}{$\alpha^{* *}$} \\
\hline & \# 1 & \# 2 & \# 3 & \# 4 & & \\
\hline I am one of the most conscientious students in the group. & 0.90 & -0.03 & -0.11 & -0.01 & $3.77(0.85)$ & 0.88 \\
\hline I do not shirk my responsibilities in the group work. & 0.90 & -0.03 & 0.00 & 0.06 & $4.23(0.65)$ & 0.87 \\
\hline $\begin{array}{l}\text { My participation in the group project activities is above the } \\
\text { norm. }\end{array}$ & 0.84 & 0.02 & -0.06 & -0.01 & $4.09(0.74)$ & 0.87 \\
\hline $\begin{array}{l}\text { I follow the ground rules of the group even when no one is } \\
\text { checking. }\end{array}$ & 0.64 & 0.09 & 0.14 & -0.03 & $4.12(0.70)$ & 0.88 \\
\hline $\begin{array}{l}\text { I believe in giving an honest amount of work for honest } \\
\text { project outcomes. }\end{array}$ & 0.59 & 0.16 & 0.03 & -0.05 & $4.03(0.73)$ & 0.89 \\
\hline $\begin{array}{l}\text { I participate in activities that are not mandatory, but are } \\
\text { considered important for the group. }\end{array}$ & 0.51 & 0.06 & 0.18 & 0.04 & $4.12(0.60)$ & 0.89 \\
\hline $\begin{array}{l}\text { I willingly help other group members who have group } \\
\text { project-related problems. }\end{array}$ & -0.02 & 0.85 & 0.07 & 0.05 & $3.91(0.67)$ & 0.83 \\
\hline $\begin{array}{l}\text { I help orient less experienced group members in the course } \\
\text { even though it is not required. }\end{array}$ & -0.00 & 0.79 & 0.04 & -0.04 & $3.82(0.70)$ & 0.84 \\
\hline I help other group members who have a heavy workload. & -0.03 & 0.77 & -0.09 & 0.02 & $3.79(0.80)$ & 0.86 \\
\hline I help other group members who have missed classes. & 0.15 & 0.65 & -0.09 & -0.01 & $3.89(0.70)$ & 0.86 \\
\hline I am always ready to lend a helping hand to group members & 0.11 & 0.64 & 0.05 & -0.01 & $3.93(0.77)$ & 0.85 \\
\hline I do not abuse the rights of other group members. & -0.15 & 0.00 & 0.95 & -0.00 & $4.15(0.63)$ & 0.65 \\
\hline I try to avoid creating problems for other group members. & 0.13 & -0.02 & 0.67 & 0.06 & $4.34(0.62)$ & 0.69 \\
\hline $\begin{array}{l}\text { I am mindful of how my attitude or behavior affects other } \\
\text { group members' work. }\end{array}$ & 0.17 & -0.01 & 0.55 & -0.08 & $3.94(0.67)$ & 0.77 \\
\hline $\begin{array}{l}\text { I consume a lot of time complaining about trivial matters in } \\
\text { the group work. }\end{array}$ & -0.08 & 0.08 & -0.08 & 0.71 & $3.79(0.92)$ & 0.70 \\
\hline $\begin{array}{l}\text { I always focus on what's wrong, rather than the positive } \\
\text { side of the group work. }\end{array}$ & 0.08 & -0.03 & -0.08 & 0.69 & $3.53(0.94)$ & 0.71 \\
\hline $\begin{array}{l}\text { I tend to make "mountains out of molehills" in the group } \\
\text { work }\end{array}$ & 0.06 & -0.13 & 0.10 & 0.68 & $4.02(0.80)$ & 0.72 \\
\hline $\begin{array}{l}\text { I am the classic "squeaky wheel" that always needs greasing } \\
\text { in the group. }\end{array}$ & -0.05 & 0.09 & 0.06 & 0.64 & $4.32(0.74)$ & 0.73 \\
\hline Mean (SD) & $\begin{array}{r}4.06 \\
(0.58)\end{array}$ & $\begin{array}{r}3.87 \\
(0.59)\end{array}$ & $\begin{array}{r}4.14 \\
(0.53)\end{array}$ & $\begin{array}{r}3.92 \\
(0.66)\end{array}$ & & \\
\hline
\end{tabular}


The first factor was conscientiousness. It consists of six items and explained $37.93 \%$ of the variance. The second factor, which consists of five items, was altruism. It explained $13.56 \%$ of the variance. The last two factors are courtesy and sportsmanship respectively. They consisted of three items and four items, and explained $7.50 \%$ and $6.39 \%$ of the variance respectively. The four factors had Cronbach alphas between 0.78 and 0.89 , which indicated a strong internal consistency of the sub-scales (Hair et al., 2006). The items, factor loadings, descriptive statistics, and Cronbach's alpha coefficient of the deleted item are shown in Table 2.

\subsection{Confirmatory factor analysis}

Confirmatory Factor Analysis (CFA) was conducted using sample \#2 (n = 277) using SPSS AMOS 25. We loaded the 18 items into the hypothesized four latent factors structured which were allowed to covary. The data fit the hypothesized four-factor model with Chi-Square/df $=1.78$. The other indexes, CFI $=.955$, TLI $=.949, \mathrm{SRMR}=.054$, and RMSEA = .053 indicate a reasonable model fit (Hair et al., 2006; Hu \& Butler, 1999). All the items are loaded significantly on the latent factors $(p<0.01)$.

\subsection{Convergent and discriminant validity}

To establish construct validity of the measure, we estimated convergent validity and discriminant validity. We examined the convergent validity using composite reliability and average variance extracted (AVE). The composite reliability, the reliability of the latent variables (four dimensions), was calculated by Fornell and Larcker's (1981) formula. In the formula, $\lambda$ is standardized factor loading and $\varepsilon$ is residual variance.

$$
\text { Composite Reliability }=\frac{\left(\sum_{i=0}^{p} \lambda_{y i}\right)^{2}}{\left(\sum_{i=0}^{p} \lambda_{y i}\right)^{2}+\sum_{i=1}^{p} \operatorname{Var}\left(\varepsilon_{i}\right)}(\text { Fornell \& Larcker, 1981, p. 45) }
$$

Table 3

Composite reliability, AVE, and inter-dimension squared correlations

\begin{tabular}{lcccccc}
\hline Dimensions & CR $^{*}$ & AVE & A. & B. & C. & D. \\
\hline A. Altruism & .92 & .70 & $(.84)^{* *}$ & & & \\
B. Conscientiousness & .95 & .75 & .45 & $(.87)$ & & \\
C. Sportsmanship & .82 & .53 & .15 & .06 & $(.73)$ & \\
D. Courtesy & .89 & .73 & .40 & .33 & .18 & $(.85)$ \\
\hline
\end{tabular}

Note. ${ }^{*}$ Composite reliability; ${ }^{* *}$ ( ) The square root of the AVE

As shown in Table 3, the reliabilities of the dimensions are ranged from .80 to .95 , which indicate strong reliability at the dimension level (Lance, Butts, \& Michels, 2006). AVE was calculated by the formula proposed by Fornell and Larcker (1981).

$$
\text { Ave }=\frac{\sum_{i=0}^{p} \lambda_{y i}^{2}}{\sum_{i=1}^{p} \lambda_{y i}^{2}+\sum_{i=1}^{p} \operatorname{Var}\left(\varepsilon_{i}\right)}(\text { Fornell and Larcker, 1981, p. 46) }
$$

As shown in Table 3, the reliabilities of the dimensions ranged from .53 to .75 , which exceed .5, the threshold suggested by Fornell and Larker (1981). Considering CR and AVE, the convergent validity of OCB-CL is adequate. 
To test discriminant validity, we calculated and compared the square root of AVE for each dimension with the corresponding inter-dimension squared correlation estimates. To support discriminant validity, the square roots of AVEs should be greater than interdimension correlations, the squared correlation of the dimension with all other dimensions (Fornell \& Larcker, 1981). As shown in Table 3, the square roots of AVEs are greater than the corresponding squared inter-dimensions, which supports the discriminant validity of the measure.

\subsection{Criterion validity}

To test the criterion validity of OCB-CL, we correlate OCB-CL with engagement and social loafing. The OCB literature suggested that OCB may increase engagement (e.g., Babcock-Roberson \& Stricklan, 2010) and reduce social loafing (e.g., Liden, Wayne, Jaworski, \& Bennett,2004; Hoon \& Tan, 2008). We used the 6-item engagement scale to measure student engagement in a work team (Schaufeli et al., 2002), and the 4-item social loafing scale to measure student social loafing (George, 1992). The OCB-CL score was negatively correlated with social loafing $(r=-0.24, p<.01)$ and positively related to engagement $(r=.37, p<.01)$.

\section{Discussion}

\subsection{Implications}

Previous OCB dimension studies argued that OCB dimensions are significantly influenced by the social and cultural contexts of OCB (Farh et al., 2004; Moorman \& Blakely, 1995). In current research, universal dimensions of OCB were confirmed in collaborative learning settings. Our results partially support previous OCB research (LePine et al., 2002), which indicates that OCB-CL dimensions can converge to four of Podsakoff et al's (1990) five dimensions.

Our results suggested that civic virtue did not sustain among the original five dimensions in collaborative learning contexts. The civic virtue items are specifically about voluntary participation in organizations (Podsakoff et al., 1990). The survey respondents in the current study might interpret participation as conscientiousness. Although we changed the context of OCB from working to learning environments, the universal dimensions of OCB were extended in the collaborative learning environment.

The majority of previous OCB research in education was primarily on teachers' OCB in their work or students' OCB in the school context (e.g., Chen \& Carey, 2009; DiPaola \& Tschannen-Moran, 2001; Koh et al., 1995). The current research clearly shows the applicability of student OCB in a collaborative learning context and provides a measurement.

Besides the methodological contribution, our research may also contribute to the understanding of collaborative learning. Johnson and Johnson (1994) identified the five elements that are needed for productive collaborative learning including positive interdependence, promotive interaction, individual accountability, interpersonal skills, and positive group process. Our study suggests that OCB as an individual attribute of students, could be another aspect that may lead students to more successful collaborative learning experiences. 


\subsection{Research limitation and future research}

A limitation of the study is the choice of the participants. We collected the data from a women's university in South Korea. It may affect the generalizability of the findings. However, there is little evidence in the OCB literature suggesting a cultural or gender effect in OCB measures. OCB instruments have been used and validated in different cultures, including Korean culture (e.g., Bourdage, Lee, Lee, \& Shin, 2012; Song, Kang, Shin, \& Kim, 2012). Previous research reported that gender moderates the effect of OCB on other variables such as workplace turnover rate and employees' self-efficacy (Beauregard, 2012; Khalid et al., 2009). However, there is little evidence that gender influences OCB measurement validation. In addition, the course that we collected data from was a general education class that involved students from all disciplines, which allowed us to examine the phenomenon from a relatively general population in higher education. The collaborative activities in the classroom were authentic and could be transferable to other cultures. Future studies may be conducted in a different culture and/or different learning environments, such as high school with a larger sample to further validate the instrument.

Another limitation is the duration of the study. Although students in the study needed to participate in 25 sessions over nine weeks, it may take longer to develop strong OCB. Nevertheless, previous OCB studies in a learning environment suggested that OCB can be developed within a semester (e.g., Allison et al., 2001; Chen \& Carey, 2009). Indeed, in the OCB literature, OCB is influenced by both dispositional and contextual variables (Konovsky \& Organ, 1996; Chiaburu, Oh, Berry, Li, \& Gardner, 2011). Therefore, we argue that OCB-CL would exist even at the beginning of the collaboration. However, individual OCB-CL may evolve over time. In college environments, students typically spend a few weeks to a maximum of 16 weeks on group projects. Therefore, we argue that a nine-week period is appropriate for the study.

Future studies may examine how OCB-CL is developed over time. Other possible future studies may validate the OCB-CL instrument and examine how OCB-CL is related to other learning constructs such as student engagement, performance, and social loafing.

\section{Discussion}

This research adapted Podsakoff et al. (1990), which is one of the most frequently used OCB scales. Our results suggested four dimensions in OCB-CL are relevant to higher education classroom settings. One dimension of the original OCB, civic virtue, was not applicable to the collaborative learning settings, while the other four dimensions: conscientiousness, altruism, courtesy, and sportsmanship were sustained.

\section{Author Statement}

The authors declare that they have no conflict of interest.

\section{ORCID}

Sung “Pil" Kang (i) https://orcid.org/0000-0001-5113-8788

JaeHwan Byun (iD) https://orcid.org/0000-0001-8240-652X 
Victor Law (D) https://orcid.org/0000-0003-3504-2764

Youn Kyung Seo (DD https://orcid.org/0000-0002-4666-7500

Kristen Ferris (iD https://orcid.org/0000-0002-9967-8633

\section{References}

Aggarwal, P., \& O’Brien, C. L. (2008). Social loafing on group projects: Structural antecedent sand effect on student satisfaction. Journal of Marketing Education, 30(3), 255-264. doi: 10.1177/0273475308322283

Alimoglu, M. K., Yardım, S., \& Uysal, H. (2017). The effectiveness of TBL with real patients in neurology education in terms of knowledge retention, in-class engagement, and learner reactions. Advances in Physiology Education, 41(1), 38-43.

Allison, B. J., Voss, R. S., \& Dryer, S. (2001). Student classroom and career success: The role of organizational citizenship behavior. Journal of Education for Business, 76(5), 282-288. doi: 10.1080/08832320109599650

Babcock-Roberson, M. E., \& Strickland, O. J. (2010). The relationship between charismatic leadership, work engagement, and organizational citizenship behaviors. The Journal of Psychology, 144(3), 313-326.

Balasooriya, C. D., Hughes, C., \& Toohey, S. (2009). Impact of a new integrated medicine program on students' approaches to learning. Higher Education Research \& Development, 28(3), 289-302. doi: 10.1080/07294360902839891

Bateman, T. S., \& Organ, D. W. (1983). Job satisfaction and the good soldier: The relationship between affect and employee "citizenship". Academy of Management Journal, 26(4), 587-595.

Beauregard, T. A. (2012). Perfectionism, self-efficacy and OCB: The moderating role of gender. Personnel Review, 41(5), 590-608.

Bourdage, J. S., Lee, K., Lee, J. H., \& Shin, K. H. (2012). Motives for organizational citizenship behavior: Personality correlates and coworker ratings of OCB. Human Performance, 25(3), 179-200. doi: 10.1080/08959285.2012.683904

Brislin, R. W. (1970). Back-translation for cross-cultural research. Journal of CrossCultural Psychology, 1(3), 185-216.

Burdett, J. (2003). Making groups work: University students' perceptions. International Education Journal, 4(3), 177-191.

Carpenter, J. M. (2006). Effective teaching methods for large classes. Journal of Family and Consumer Sciences Education, 24(2), 13-23.

Chahal, H., \& Mehta, S. (2010). Antecedents and consequences of organizational citizenship behavior (OCB): A conceptual framework in reference to health care sector. Journal of Services Research, 10(2), 25-44.

Chen, J., Wang, M., Kirschner, P. A., \& Tsai, C. C. (2018). The role of collaboration, computer use, learning environments, and supporting strategies in CSCL: A metaanalysis. Review of Educational Research, 88(6), 799-843. doi: 10.3102/0034654318791584

Chen, J., Wang, M., Kirschner, P. A., \& Tsai, C. C. (2019). A meta-analysis examining the moderating effects of educational level and subject area on CSCL effectiveness. Knowledge Management \& E-Learning, 11(4), 409-427.

Chen, S. X., \& Carey, T. P. (2009). Assessing citizenship behavior in educational contexts: The role of personality, motivation, and culture. Journal of Psychoeducational Assessment, 27(2), 125-137. doi: 10.1177/0734282908325146

Chiaburu, D. S., Oh, I. S., Berry, C. M., Li, N., \& Gardner, R. G. (2011). The five-factor 
model of personality traits and organizational citizenship behaviors: A meta-analysis. Journal of Applied Psychology, 96(6), 1140-1166.

Ching, Y. H., \& Hsu, Y. C. (2013). Collaborative learning using VoiceThread in an online graduate course. Knowledge Management \& E-Learning, 5(3), 298-314.

Costello, A. B., \& Osborne, J. (2005). Best practices in exploratory factor analysis: Four recommendations for getting the most from your analysis. Practical Assessment, Research \& Evaluation, 10(10): 7.

Deeter-Schmelz, D. R., Kennedy, K. N., \& Ramsey, R. P. (2002). Enriching our understanding of student team effectiveness. Journal of Marketing Education, 24(2), 114-124. doi: 10.1177/0273475302242004

Delucchi, M. (2006). The efficacy of collaborative learning groups in an undergraduate statistics course. College Teaching, 54(2), 244-248.

Dillenbourg, P. (1999). What do you mean by "collaborative learning"? In P. Dillenbourg (Ed.), Collaborative learning: Cognitive and computational approaches (pp. 1-16). Amsterdam, NL: Pergamon, Elsevier Science.

DiPaola, M., \& Tschannen-Moran, M. (2001). Organizational citizenship behavior in schools and its relationship to school climate. Journal of School Leadership, 11(5), 424-447.

DiPaola, M. F., \& Hoy, W. K. (2005). Organizational citizenship of faculty and achievement of high school students. The High School Journal, 88(3), 35-44.

Ehrhart, M. G., \& Naumann, S. E. (2004). Organizational citizenship behavior in work groups: A group norms approach. Journal of Applied Psychology, 89(6), 960-974.

Espey, M. (2010). Valuing teams: What influences student attitudes? NACTA Journal, 54, $31-40$.

Fabrigar, L. R., \& Wegener, D. T. (2012). Exploratory factor analysis. Oxford, UK: Oxford University Press.

Farh, J. L., Zhong, C. B., \& Organ, D. W. (2004). Organizational citizenship behavior in the People's Republic of China. Organization Science, 15(2), 241-253.

Ferguson, E., \& Cox, T. (1993). Exploratory factor analysis: A users' guide. International Journal of Selection and Assessment, 1(2), 84-94.

Fornell, C., \& Larcker, D. F. (1981). Evaluating structural equation models with unobservable variables and measurement error. Journal of Marketing Research, 18(1), $39-50$.

George, J. M. (1992). Extrinsic and intrinsic origins of perceived social loafing in organizations. Academy of Management Journal, 35(1), 191-202.

Gillespie, D., Rosamond, S., \& Thomas, E. (2006). Grouped out? Undergraduates' default strategies for participating in multiple groups. The Journal of General Education, 55(2), 81-102.

Gokhale, A. A. (1995). Collaborative learning enhances critical thinking. Journal of Technology Education, 7(1), 22-30.

Goodsell, A. S., Maher, M. R., Tinto, V., Smith, B. L., \& MacGregor, J. (1992). Collaborative learning: A sourcebook for higher education. National Center on Postsecondary Teaching, Learning, and Assessment, Pennsylvania State University, University Park, PA, USA.

Gottschall, H., \& García-Bayonas, M. (2008). Student attitudes towards group work among undergraduates in business administration, education and mathematics. Educational Research Quarterly, 32(1), 3-28.

Hair, J. F., Black, W. C., Babin, B.J., Anderson, R. E., \& Tatham, R. L. (2006). Multivariate data analysis (6th ed.). Upper Saddle River, NJ: Pearson.

Hoon, H., \& Tan, T. M. L. (2008). Organizational citizenship behavior and social loafing: The role of personality, motives, and contextual factors. The Journal of Psychology, 142(1), 89-108. 
Hu, L., \& Butler, P. M. (1999). Cutoff criteria for fit indices in covariance structure analysis: Conventional criteria versus new alternatives. Structural Equation Modeling, $6,1-55$.

Johnson, D. W., \& Johnson, R. T. (1989). Cooperation and competition: Theory and research. Edina, MN: Interaction Book Company.

Johnson, R. T., \& Johnson, D. W. (1994). An overview of cooperative learning. In J. S. Thousand, R. A. Villa, \& A. I. Nevin (Eds.), Creativity and collaborative learning: A practical guide to empowering students and teachers (pp. 31-44). Baltimore, MD: Brookes Publishing.

Jungert, T., Van den Broeck, A., Schreurs, B., \& Osterman, U. (2018). How colleagues can support each other's needs and motivation: An intervention on employee work motivation. Applied Psychology, 67(1), 3-29.

Keszei, A. P., Novak, M., \& Streiner, D. L. (2010). Introduction to health measurement scales. Journal of Psychosomatic Research, 68(4), 319-323.

Khalid, S. A., Jusoff, H. K., Ali, H., Ismail, M., Kassim, K. M., \& Rahman, N. A. (2009). Gender as a moderator of the relationship between OCB and turnover intention. Asian Social Science, 5(6), 108-117.

Knox, K. J., Gillis, E. A. L., \& Dake, G. R. (2019). A positive student experience of collaborative project work in upper-year undergraduate chemistry. Chemistry Education Research and Practice, 20, 340-357.

Koh, W. L., Steers, R. M., \& Terborg, J. R. (1995). The effects of transformational leadership on teacher attitudes and student performance in Singapore. Journal of Organizational Behavior, 16(4), 319-333.

Kondo, A. E., \& Fair J. D. (2017). Insight into the chemistry skills gap: The duality between expected and desired skills. Journal of Chemistry Education, 94, 304-310.

Konovsky, M. A., \& Organ, D. W. (1996). Dispositional and contextual determinants of organizational citizenship behavior. Journal of Organizational Behavior, 17(3), 253266.

Koys, D. J. (2001). The effects of employee satisfaction, organizational citizenship behavior, and turnover on organizational effectiveness: A unit-level, longitudinal study. Personnel Psychology, 54(1), 101-114.

Kreijns, K., Kirschner, P. A., \& Jochems, W. (2003). Identifying the pitfalls for social interaction in computer-supported collaborative learning environments: A review of the research. Computers in Human Behavior, 19(3), 335-353. doi: 10.1016/S07475632(02)00057-2

Laal, M., \& Ghodsi, S. M. (2012). Benefits of collaborative learning. Procedia-Social and Behavioral Sciences, 31, 486-490.

Lance, C. E., Butts, M. M., \& Michels, L. C. (2006). The sources of four commonly reported cutoff criteria: What did they really say? Organizational Research Methods, 9(2), 202-220.

Lee, H., Parsons, D., Kwon, G., Kim, J., Petrova, K., Jeong, E., \& Ryu, H. (2016). Cooperation begins: Encouraging critical thinking skills through cooperative reciprocity using a mobile learning game. Computers \& Education, 97, 97-115.

LePine, J. A., Erez, A., \& Johnson, D. E. (2002). The nature and dimensionality of organizational citizenship behavior: A critical review and meta-analysis. Journal of Applied Psychology, 87(1), 52-65.

LePine, J. A., Piccolo, R. F., Jackson, C. L., Mathieu, J. E., \& Saul, J. R. (2008). A meta-analysis of teamwork processes: Tests of a multidimensional model and relationships with team effectiveness criteria. Personnel Psychology, 61(2), 273-307.

Li, N., Kirkman, B. L., \& Porter, C. O. L. H. (2014). Toward a model of work team altruism. Academy of Management Review, 39(4), 541-565. 
Liden, R. C., Wayne, S. J., Jaworski, R. A., \& Bennett, N. (2004). Social loafing: A field investigation. Journal of Management, 30(2), 285-304.

Lim, D. H., Morris, M. L., \& McMillan, H. S. (2011). Construct validation of the translated version of the work-family conflict scale for use in Korea. Human Resource Development Quarterly, 22(4), 519-543. doi: 10.1002/hrdq.20089

Lin, C. C. T., \& Peng, T. K. (2010). From organizational citizenship behaviour to team performance: The mediation of group cohesion and collective efficacy. Management and Organization Review, 6(1), 55-75.

Lou, Y., Abrami, P. C., \& d'Apollonia, S. (2001). Small group and individual learning with technology: A meta-analysis. Review of Educational Research, 71(3), 449-521. doi: 10.3102/00346543071003449

MacKenzie, S. B., Podsakoff, P. M., \& Fetter, R. (1993). The impact of organizational citizenship behavior on evaluations of salesperson performance. Journal of Marketing, 57(1), 70-80.

Medero, G. S., \& Albaladejo, G. P. (2020). The use of a wiki to boost open and collaborative learning in a Spanish university. Knowledge Management \& E-Learning, 12(1), 1-17.

Micari, M., \& Pazos, P. (2019). Small fish in a small pond: The impact of collaborative learning on academic success for less-prepared students in a highly selective stem environment. Higher Education Research \& Development, 38(2), 294-306. doi: 10.1080/07294360.2018.1532395

Moorman, R. H., \& Blakely, G. L. (1995). Individualism-collectivism as an individual difference predictor of organizational citizenship behavior. Journal of Organizational Behavior, 16(2), 127-142.

Myers, S. A. (2012). Students' perceptions of classroom group work as a function of group member selection. Communication Teacher, 26(1), 50-64. doi: 10.1080/17404622.2011.625368

Nielsen, T. M., Hrivnak, G. A., \& Shaw, M. (2009). Organizational citizenship behavior and performance: A meta-analysis of group-level research. Small Group Research, 40(5), 555-577.

Organ, D. W. (1988). Organizational citizenship behavior: The good soldier syndrome. Lexington, MA: Lexington Books.

Pai, H.-H., Sears, D. A., \& Maeda, Y. (2015). Effects of small-group learning on transfer: A meta-analysis. Educational Psychology Review, 27(1), 79-102. doi: 10.1007/s10648-014-9260-8

Podsakoff, N. P., Whiting, S. W., Podsakoff, P. M., \& Blume, B. D. (2009). Individualand organizational-level consequences of organizational citizenship behaviors: A meta-analysis. Journal of Applied Psychology, 94(1), 122-141.

Podsakoff, P. M., Ahearne, M., \& MacKenzie, S. B. (1997). Organizational citizenship behavior and the quantity and quality of work group performance. Journal of Applied Psychology, 82(2), 262-270.

Podsakoff, P. M., \& MacKenzie, S. B. (1994). An examination of the psychometric properties and nomological validity of some revised and reduced substitutes for leadership scales. Journal of Applied Psychology, 79(5), 702-713.

Podsakoff, P. M., \& MacKenzie, S. B. (1997). Impact of organizational citizenship behavior on organizational performance: A review and suggestion for future research. Human Performance, 10(2), 133-151.

Podsakoff, P. M., MacKenzie, S. B., Moorman, R. H., \& Fetter, R. (1990). Transformational leader behaviors and their effects on followers' trust in leader, satisfaction, and organizational citizenship behaviors. The Leadership Quarterly, 1(2), 107-142.

Prasarnphanich, P., \& Wagner, C. (2009). The role of wiki technology and altruism in 
collaborative knowledge creation. Journal of Computer Information Systems, 49(4), 33-41.

Russell, D. W. (2002). In search of underlying dimensions: The use (and abuse) of factor analysis in personality and social psychology bulletin. Personality and Social Psychology Bulletin, 28(12), 1629-1646. doi: 10.1177/014616702237645

Sanson-Fisher, R. W., \& Perkins, J. J. (1998). Adaptation and validation of the SF-36 health survey for use in Australia. Journal of Clinical Epidemiology, 51(11), 961-967.

Schaufeli, W. B., Salanova, M., González-Romá, V., \& Bakker, A. B. (2002). The measurement of engagement and burnout: A two sample confirmatory factor analytic approach. Journal of Happiness Studies, 3(1), 71-92.

Smith, C. A., Organ, D. W., \& Near, J. P. (1983). Organizational citizenship behavior: Its nature and antecedents. Journal of Applied Psychology, 68(4), 653-663.

Song, J. H., Kang, I. G., Shin, Y. H., \& Kim, H. K. (2012). The impact of an organization's procedural justice and transformational leadership on employees' citizenship behaviors in the Korean business context. Journal of Leadership \& Organizational Studies, 19(4), 424-436. doi: 10.1177/1548051812446659

Sun, L. Y., Aryee, S., \& Law, K. S. (2007). High-performance human resource practices, citizenship behavior, and organizational performance: A relational perspective. Academy of Management Journal, 50(3), 558-577.

Tabachnick B. G., \& Fidell L. S. (2007). Using multivariate statistics. Boston, MA: Pearson Education.

Tlhoaele, M., Hofman, A., Winnips, K., \& Beetsma, Y. (2014). The impact of interactive engagement methods on students' academic achievement. Higher Education Research \& Development, 33(5), 1020-1034. doi: 10.1080/07294360.2014.890571

Volet, S., \& Mansfield, C. (2006). Group work at university: Significance of personal goals in the regulation strategies of students with positive and negative appraisals. Higher Education Research \& Development, 25(4), 341-356. doi: 10.1080/07294360600947301

Walz, S. M., \& Niehoff, B. P. (2000). Organizational citizenship behaviors: Their relationship to organizational effectiveness. Journal of Hospitality \& Tourism Research, 24(3), 301-319. 